\title{
Grooved stone tools from Calabria region (Italy): Archaeological evidence and research perspectives
}

\author{
Felice Larocca, Francesco Breglia
}

Università degli Studi di Bari Aldo Moro, Gruppo di Ricerca Speleo-Archeologica, Piazza Umberto I n. 1, 70121

Bari, Italy. and Centro Regionale di Speleologia “Enzo dei Medici”, Via Lucania n. 3, 87070 Roseto Capo

Spulico, Cosenza, Italy. Email: Larocca: specus@tin.it; Breglia: francescobreglia@email.it

\begin{abstract}
:
Since the end of the $19^{\text {th }}$ century the Calabria region in southern Italy has been known for an abundance of grooved stone axes and hammers used during late prehistory. These artefacts are characterized by a wide and often pronounced groove in the middle of the implement, thought to have aided securing the head to a wooden haft. Their widespread presence is known both in prehistoric archaeological literature and in the archaeological collections of various regional and extra-regional museums. At first, scholars did not relate these tools to the rich Calabrian ore deposits and to possible ancient mining activities; they were regarded simply as a variant of ground lithic industry of Neolithic tradition. However, between 1997 and 2012, about 50 tools were discovered in the prehistoric mine of Grotta della Monaca in northern Calabria where there are outcrops of copper and iron ore. This allowed us to recognize their specific mining value and to consider them as a sort of "guide fossil" for the identification of ancient mining districts. This paper presents the results of a study involving over 150 tools from the entire region, effectively demonstrating an almost perfect co-occurrence of grooved axes and hammers with areas rich in mineral resources, especially metalliferous ores.
\end{abstract}

Keywords: grooved stone tools; Italy; Calabria; prehistory; mines; ground stone tools

\section{Introduction}

In Calabria, the southernmost region of the Italian peninsula, research and systematically collecting of ground stone tools - particularly stone hatchets - began at the end of the nineteenth century, when scholars and other enthusiasts of local history started to show interest in the antiquities of the region. Previously, mountain people, farmers, and shepherds were interested in these items, which they believed magical, interpreting them as the effect of the impact of lightning on the ground. For this reason, these objects were called "thunderstones" and for many centuries were linked to apotropaic or even therapeutic powers. To some, however, their properties possessed a negative power, and when these stones were accidentally found in the fields people preferred not to touch them (Lovisato 1878a).

The recognition that these artefacts were made by prehistoric people was universally accepted in the late nineteenth century. In the first publications, characterized by a medley of

Published by the School of History, Classics and Archaeology, University of Edinburgh ISSN: 2055-0472. URL: http://journals.ed.ac.uk/lithicstudies/

This work is licensed under a Creative Commons Attribution 2.5 UK: Scotland License. 
geological and palaeoethnological aspects, collections of tools found in different districts of the region are discussed. In addition to the abundant hatchets of various shapes and size, hammers or hammer-axes (characterized by the presence of a visible groove on the lithic body) began to appear, sporadically at first, then more and more frequently.

Hammer-axes are characterized by the presence of an evident groove near the midpoint between a sharpened axe blade end, and the flat hammer-shaped end. Hammers instead are so defined because they have two flattened ends.

Lovisato understood that the groove represented a means by which to haft the implement, and using ethnographic comparisons proposed a graphic reconstruction of the tools appearance when hafted on its wooden handle (Lovisato 1878b) (Figure 1A). Later, grooved tools attracted the attention of many other scholars, including Topa, who created a typology of so-called "grooved stone hammers" in a work on the "primitive cultures" of Calabria (Topa 1927) (Figure 1B).

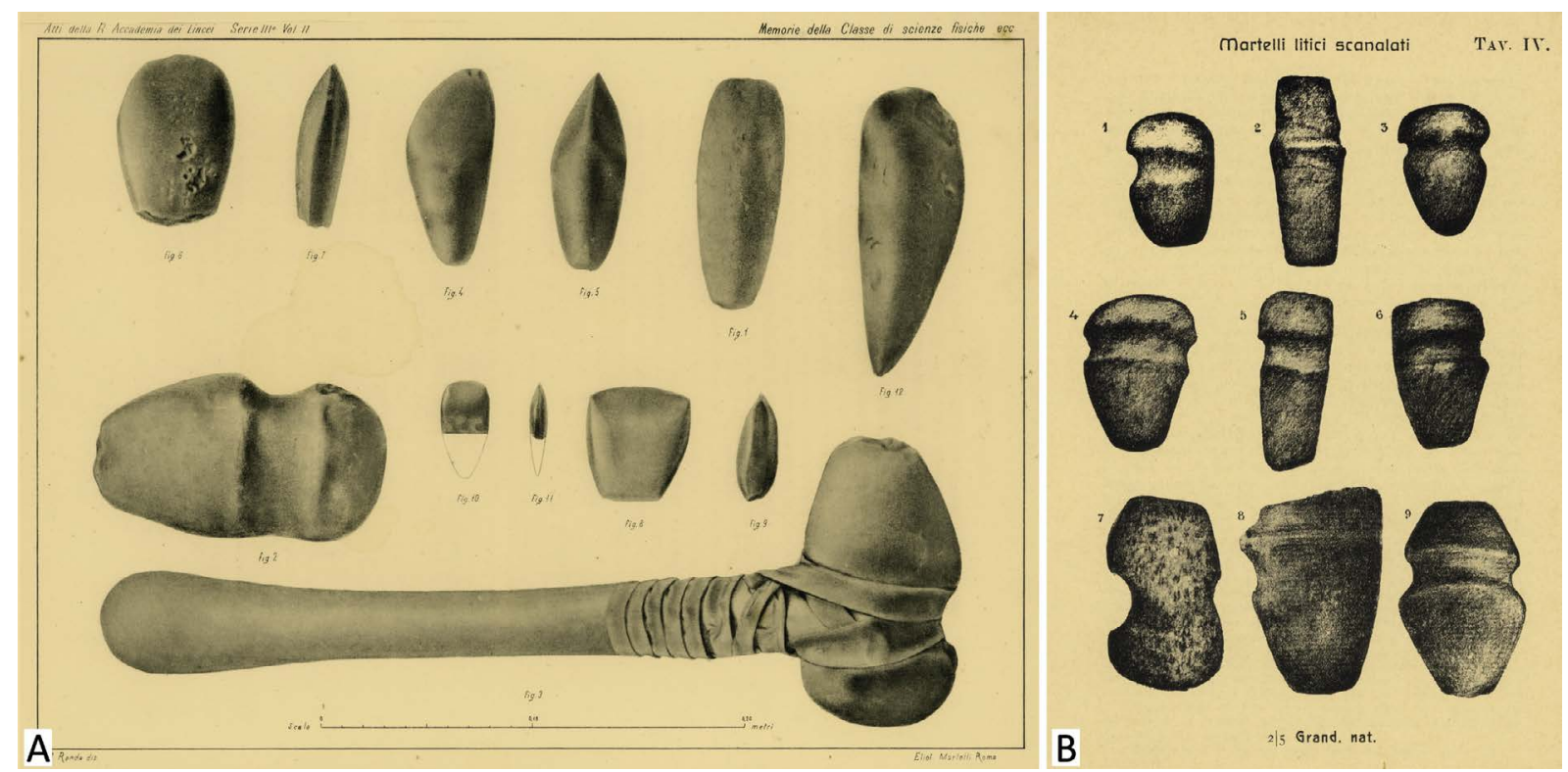

Figure 1. A. Drawings of polished stone industry from Calabria, including a grooved tool with and without the wooden handle (Lovisato 1878b). B. Graphical representation of nine "grooved stone hammers" found in Calabria (Topa 1927).

Collections built up over many years, thanks to the passionate research of a multitude of scholars, and were later acquired by different Calabrian, Italian, and often foreign museums, with the result that today these objects are dispersed widely and are often found in a very fragmented condition. The widespread presence of these objects in Calabria does not seem accidental. They were designed as heavy percussion tools and required the use of particularly durable rocks to fulfil their purpose. The Calabrian territory, thanks to its geological features, includes extensive outcrops of durable rocks. The boundaries of the region fall almost entirely in the Calabria-Peloritani Arch (CPA), a large portion of alpine origin crust, with its characteristic arched shape interposed between the Maghrebides and the southern Apennines (Amodio-Morelli et al. 1976).

Structurally, the CPA is characterized by the coexistence of different crystallinemetamorphic Palaeozoic and Cretaceous units derived from deformation and metamorphosis of both continental and oceanic crust. This is the reason for the exceptional variety of durable rocks (both igneous and metamorphic) throughout the region, except for its northernmost portion, where the carbonatic mountains of the southern Apennines are found. The complex geological history of the region determined a marked lithological variability, as well as the 
presence of rich and diversified mineral deposits. Using the available information (Bonardi et al. 1982; Guarascio 1982; De Vivo et al. 1984) we are able to approximately locate a series of polymetallic and copper prevalent deposits. In summary, deposits are grouped into five areas: one in the northwest of the province of Cosenza; the second in the northern part of the Sila massif; the third in the centre of the region, north of the Catanzaro isthmus; the fourth is located in the southeast in the Calabrian Serre area; the last one in the far south of the region, in the coastal strip west of Aspromonte, near Reggio Calabria.

\section{Tools}

We do not exactly know how many stone tools have been found so far in Calabria. By combining specimens kept in museums (within and outside Calabria), held in private collections, cited by palaeoethnological literature, and those discovered by archaeological research missions still operating in the area, we calculate that there are approximately 250 . For the sake of brevity, we consider only three specific groups of grooved tools: 1) a collection at the Museo Archeologico Provinciale in Catanzaro; 2) a collection held at the Museo Nazionale Preistorico Etnografico "Luigi Pigorini” in Rome; and 3) the set of artefacts unearthed in the site of Grotta della Monaca in Sant'Agata di Esaro (Cosenza).

Eight grooved tools belonging to the so-called "Foderaro Collection" are held at the Museo Archeologico Provinciale in Catanzaro. Giuseppe Foderaro, Vice Director of the Museum of Catanzaro in the late nineteenth century, collected a considerable number of prehistoric lithic objects from Calabria (over 500 finds) during his career as an engineer building bridges and roads, which he donated to the museum. The eight grooved tools discussed here belong to the typological category of hammer-axes. The provenience is known for only six tools (Palermiti, Zagarise, Nocera Terinese and Cortale, all towns in the province of Catanzaro), although remaining two certainly originate in the same province. Two artefacts derive from Palermiti and Nocera Terinese, whereas Zagarise and Cortale had only one each (Figure 2). They are all intact and their weights vary from a maximum of $1790 \mathrm{~g}$ to a minimum of $335 \mathrm{~g}$.
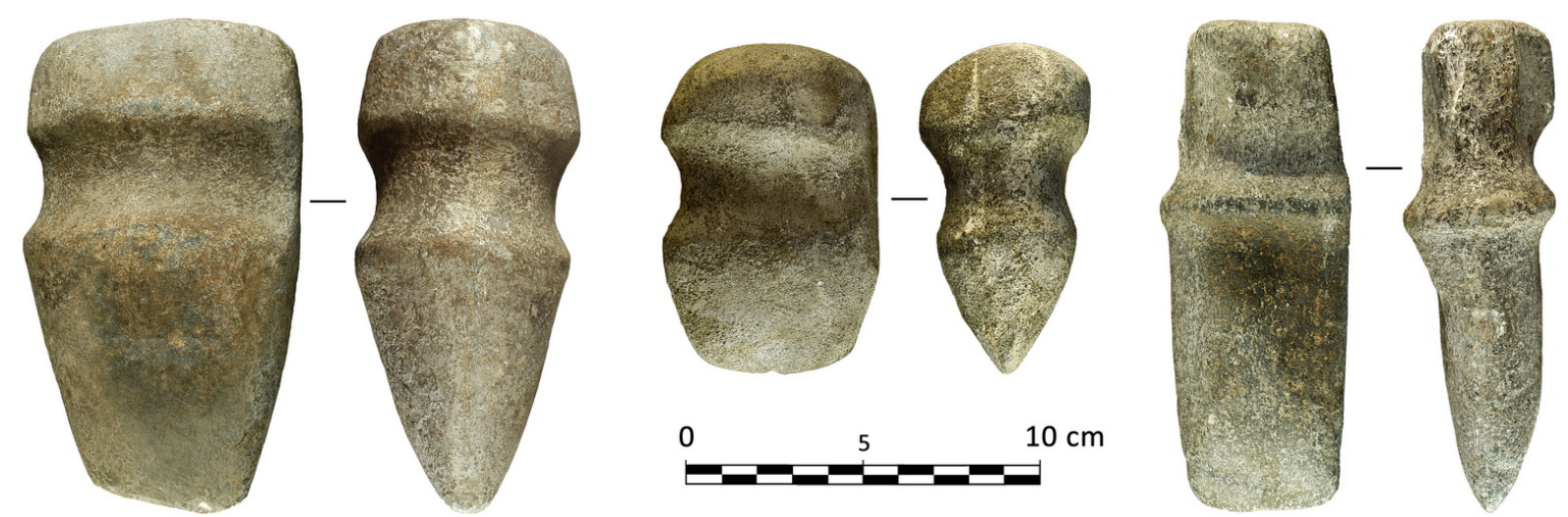

Figure 2. Grooved hammer-axes kept in the Museo Archeologico Provinciale in Catanzaro: A. from Palermiti (Catanzaro), ID 1003; B. from Zagarise (Catanzaro), ID 1005; C. from Cortale (Catanzaro), ID 1004

In six specimens, grooves are present on three sides of the tool (on the two flat faces and one short side), while in two cases the groove goes all around the tool. The lithologies of these tools have not been precisely determined by petrographic analysis, but macroscopic observation indicates all seem to be igneous or metamorphic (Table 1). In most cases, the geological substrate of the areas in which these tools come from consists of metamorphic rocks, but extensive outcrops of igneous rocks are also available. In the Palermiti territory granites and granodiorites abound, as well as prealpine high-grade metamorphic rocks (i.e., 
granulites, gneiss, anphibolites), the last are common also in Zagarise and Cortale surroundings; in the Nocera Terinese territory low-grade metamorphic rocks (i.e., phyllites, porphyroids, marbles and greenschists) abound, but limited ophiolitic and green stone intrusions (i.e., serpentines, serpentine schists, chlorite schists) are also present. Given the broad availability of these raw materials, a local provenience of lithic resources is highly plausible, presumably in the form of pebbles from riverbanks.

Table 1. ID and quantitative data of the eight grooved tools kept in the Museo Archeologico Provinciale in Catanzaro. Abbreviations: L - length (cm); MT - maximum thickness (cm); AWd - average width (cm); AD average depth (cm); Wt - weight (grams).

\begin{tabular}{llcccccc}
\hline & & & & \multicolumn{3}{c}{ Hafting Index Measures } \\
ID & Provenance & Type & $\mathbf{L}$ & MT & AWd & AD & Wt \\
\hline 1003 & Palermiti & hammer-axe & 13.9 & 6.3 & 2.8 & 0.6 & 1205 \\
1005 & Zagarise & hammer-axe & 9.3 & 5.0 & 2.7 & 0.7 & 424 \\
1006 & Nocera Terinese & hammer-axe & 9.6 & 3.5 & 1.9 & 0.4 & 386 \\
891 & unknown (Catanzaro province) & hammer-axe & 8.0 & 4.2 & 2.15 & 0.4 & 335 \\
1002 & Palermiti & hammer-axe & 17.5 & 7.8 & 3.6 & 1.0 & 1570 \\
1001 & Nocera Terinese & hammer-axe & 14.7 & 7.6 & 3.55 & 0.8 & 1790 \\
890 & unknown (Catanzaro province) & hammer-axe & 13.2 & 5.5 & 2.8 & 0.8 & 922 \\
1004 & Cortale & hammer-axe & 13.8 & 3.7 & 2.35 & 0.6 & 508 \\
\hline
\end{tabular}

The grooved artefacts preserved in Rome at the Museo Nazionale Preistorico ed Etnografico "Luigi Pigorini" also come from nineteenth century collections (Salerno \& Pessina 2004). These include twenty-three instruments collected from various locations in central and southern Calabria. From north to south, these originate in Longobucco, Spezzano della Sila, Cicala, Gimigliano, Roccaforte del Greco and Bova (Figure 3).

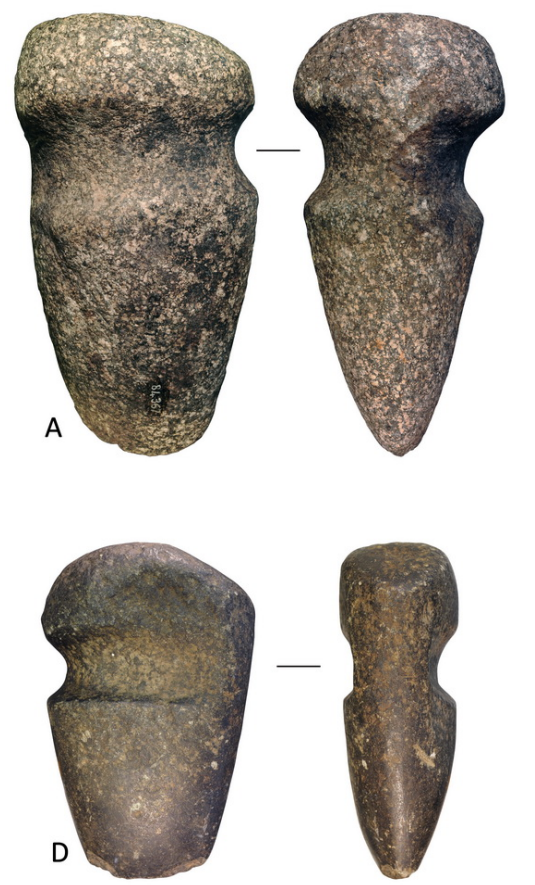

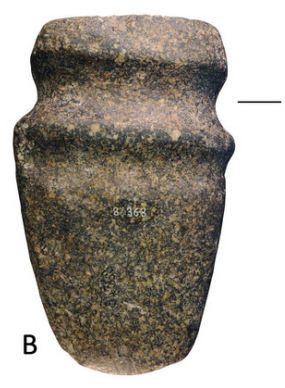
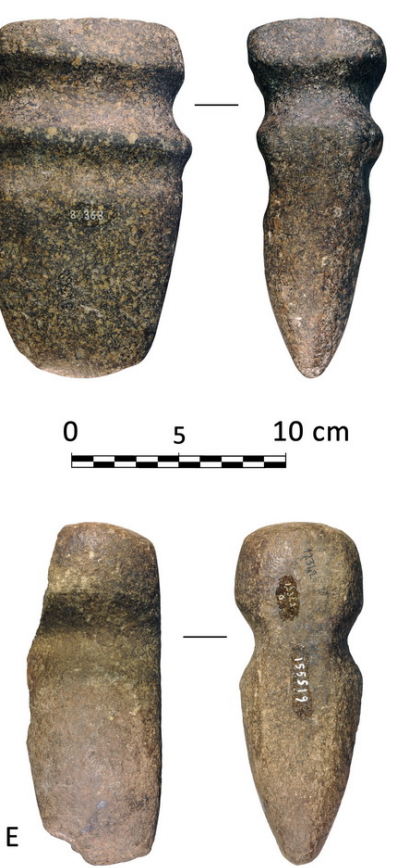
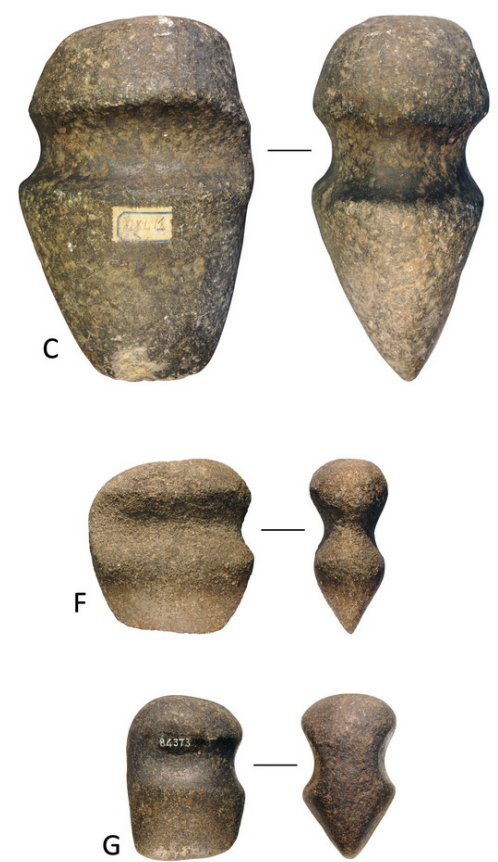

Figure 3. Grooved hammer-axes kept at the Museo Nazionale Preistorico Etnografico "Luigi Pigorini" in Rome: A-B. From Cicala (Catanzaro), ID 84367 / ID 84368; C-D. From Roccaforte del Greco (Reggio Calabria), ID 84364 / ID 84365; E-F. From Longobucco (Cosenza), ID 12342 G / ID 13007 G; G. From Cicala (Catanzaro), ID 84373. 
In this collection hammer-axes are again the most frequent tool type; however, there are also some examples of hammers. The majority of the artefacts are intact: only a few of them are fragmentary or incomplete due to the detachment of chips. This is hardly surprising if we consider that the phenomenon of $\left(19^{\text {th }}\right.$-early $20^{\text {th }}$ century) collecting tended to select objects on the basis of integrity and aesthetic value. We also have to keep in mind that often collectors acquired these tools from farmers and shepherds, who picked them because they were intrigued by the particular morphology of this type of object; it would have been easier to identify these distinctive objects if they were intact rather than fragmented. As the dimensions of grooved tools kept in Museo Pigorini are highly variable, their weight also varies from a maximum of $3158 \mathrm{~g}$ (a huge hammer-axe from Cicala) to a minimum of $151 \mathrm{~g}$ (a tiny hatchet from unknown location in the province of Reggio Calabria) (Table 2).

Eighteen out of a total of twenty-three instruments have a groove on only three sides of the lithic body, three specimens show a continuous groove on all four faces, and in only one case the groove is located on two sides of the tool (a globular percussor). In another case unique in the Roman collection - there are two grooves on the same tool, one of which is set on three faces of the instrument, the other one on all its sides. Unlike grooved tools kept in the Museum of Catanzaro, we were able to conduct accurate petrographic analyses by taking microcore samples from these tools. The spectrum of stone materials emerging from these analyses is quite wide. All of the artefacts are made of igneous or metamorphic rocks. Eleven igneous specimens include six gabbros, two porphyry, two dacites, and one diorite. The remaining twelve artefacts are made of metamorphic rock: three gneiss, three schists, three actinolites, one metagabbro, one metarenite, and one amphibolite. All of the recognized rock types are available in the vicinity of the find locations of the tools and again, based on their morphological features, it is conceivable that they were collected as pebbles along the banks of the many streams that flow through the region.

So far, the grooved artefacts unearthed in the underground site of Grotta della Monaca are the only ones to have been precisely located. Grotta della Monaca is a karst cave over half a kilometre deep, rich in iron and copper mineralization. It opens at 600 meters above sea level in the upper River Esaro Valley, not far from the town of Sant'Agata di Esaro (province of Cosenza). In the cave twenty-two intact or almost intact grooved stone tools have been recovered, as well as a large number of chips and fragments varying in size, which imply at least another thirty similar artefacts. Specifically, twenty-nine flakes and twenty fragments of tools were found. Five of the latter have a longitudinal fracture; three specimens show a longitudinal and transverse fracture, and the remaining are large fragments detached from the tools in an irregular fashion.

In several cases it was possible to refit the fragments and flakes to the broken instruments, allowing us to demonstrate that the artefacts were damaged inside the cavity and often to identify the exact point where the tools were used. The fracture types depend on the mechanical properties of the different rocks: in the case of rocks with isotropic structure, the artefacts tend to lose small flakes from the functional edge; in the case of rocks with schistose structure, longitudinal fractures (or in any case along the stratification planes) are frequent. In any case all the breaks are due to heavy impact. The reason for the abundance of grooved tools at this site certainly has to be linked to the rich ore deposits inside the cavern (Larocca 2005; 2010). In several cases fragments and flakes have been found in secure stratigraphic positions and the mining deposits they were found within have been radiocarbon dated. Mining activities in Grotta della Monaca are placed in a chronological horizon between the late fifth and early fourth millennium B.C. The implements found in Grotta della Monaca fall into three basic typological categories: hammer-axes, hammers and pickaxes (Figure 4). We have already defined the first two types in discussion of the finds kept in the Museums of Rome and Catanzaro. The pickaxes are a peculiarity of Grotta della Monaca: they have a sub- 
pyramidal or sub-conical pointed end and may have notches, instead of a groove (or grooves), for anchoring the wooden handle. Statistically, the most numerous artefacts are hammers (18 specimens), followed by the hammer-axes (6 copies) and pickaxes (5 specimens).

Table 2. ID and quantitative data of the twenty-three grooved tools kept in the Museo Nazionale Preistorico Etnografico "Luigi Pigorini” in Rome. Abbreviations: L - length (cm); MT - maximum thickness (cm); AWd average width (cm); AD - average depth (cm); Wt - weight (grams).

\begin{tabular}{|c|c|c|c|c|c|c|c|}
\hline \multirow[b]{2}{*}{ ID } & \multirow[b]{2}{*}{ Provenance } & \multirow[b]{2}{*}{ Type } & \multirow[b]{2}{*}{$\mathbf{L}$} & \multirow[b]{2}{*}{ MT } & \multicolumn{2}{|c|}{ Hafting Index Measures } & \multirow[b]{2}{*}{ Wt } \\
\hline & & & & & AW & AD & \\
\hline 84367 & Cicala & hammer-axe & 20.6 & 9.75 & 4.7 & 1.1 & 3158 \\
\hline 84368 & Cicala & hammer-axe & 16.7 & 6.4 & $\begin{array}{c}1^{\text {st }} \text { groove } \\
3.0 \\
2^{\text {nd }} \text { groove } \\
2.6\end{array}$ & $\begin{array}{l}1^{\text {st }} \text { groove } \\
0.6 \\
2^{\text {nd }} \text { groove } \\
0.4\end{array}$ & 1626 \\
\hline 84369 & Cicala & hammer-axe & 13.45 & 5.5 & 4.2 & 0.8 & 900 \\
\hline 84376 & Cicala & hammer-axe & 11.15 & 4.4 & 2.8 & 0.5 & 613 \\
\hline 84364 & $\begin{array}{l}\text { Roccaforte del } \\
\text { Greco }\end{array}$ & hammer-axe & 17.0 & 8.1 & 3.9 & 0.9 & 2252 \\
\hline 84365 & $\begin{array}{l}\text { Roccaforte del } \\
\text { Greco }\end{array}$ & hammer-axe & 15.65 & 5.5 & 3.3 & 0.9 & 1331 \\
\hline 84418 & Bova & hammer-axe & 13.25 & 5.0 & 3.2 & 0.8 & 736 \\
\hline 84366 & $\begin{array}{l}\text { Spezzano della } \\
\text { Sila }\end{array}$ & hammer-axe & 14.1 & 5.9 & 3.0 & 0.8 & 1472 \\
\hline 84340 & Gimigliano & hammer-axe & 11.95 & 5.3 & 2.5 & 0.4 & 683 \\
\hline 84457 & $\begin{array}{l}\text { Roccaforte del } \\
\text { Greco }\end{array}$ & hammer-axe & 11.55 & 3.8 & 3.1 & 0.6 & 649 \\
\hline 84459 & $\begin{array}{l}\text { Roccaforte del } \\
\text { Greco }\end{array}$ & hammer-axe & 12.95 & 4.5 & 3.1 & 0.6 & 680 \\
\hline 84456 & $\begin{array}{l}\text { Roccaforte del } \\
\text { Greco }\end{array}$ & hammer-axe & 14.9 & 7.2 & 4.4 & 1.0 & 1537 \\
\hline 84417 & Bova & hammer-axe & 10.5 & 3.5 & 2.9 & 0.5 & 497 \\
\hline 84453 & $\begin{array}{l}\text { Roccaforte del } \\
\text { Greco }\end{array}$ & & 19.2 & 5.6 & 3.4 & 0.9 & 2004 \\
\hline 84455 & $\begin{array}{l}\text { Roccaforte del } \\
\text { Greco }\end{array}$ & hammer & 13.9 & 5.9 & 3.3 & 0.8 & 1374 \\
\hline 84454 & $\begin{array}{l}\text { Roccaforte del } \\
\text { Greco }\end{array}$ & hammer-axe & 15.7 & 6.0 & 3.9 & 0.9 & 970 \\
\hline 12342 G & Longobucco & hammer-axe & 15.9 & 6.2 & 3.8 & 0.8 & 1104 \\
\hline 6931 & unknown & hammer-axe & 12.0 & 5.7 & 3.5 & 0.7 & 789 \\
\hline 84433 & unknown & hammer-axe & 8.5 & 6.8 & - & - & 827 \\
\hline 32912 & Soverato Turrati & $\begin{array}{l}\text { globular } \\
\text { percussor }\end{array}$ & 6.4 & 5.7 & 1.7 & 0.2 & 353 \\
\hline 13007 G & Longobucco & hammer-axe & 8.1 & 3.8 & 3.0 & 0.6 & 392 \\
\hline 84373 & Cicala & hammer-axe & 7.7 & 4.6 & 3.2 & 0.5 & 337 \\
\hline 84443 & unknown & hammer-axe & 8.4 & 2.9 & 1.8 & 1.2 & 151 \\
\hline
\end{tabular}

The typological variability (hammer-axes, hammers and pickaxes) certainly reflects a different function of the various instruments. The size of the tools is as variable as their weight: the latter ranges from $3115 \mathrm{~g}$ for the biggest specimen to $617 \mathrm{~g}$ for the smallest one (Table 3). The large size variability of these artefacts also indicates that they may have been put to different purposes. The dimensions are related both to the specific activity (e.g., 
excavation in the ground, indirect percussion on chisels or wedges, direct disintegration of the wall rock, roughing of extracted ore, etc.) and to the features of the extractive front, particularly to the shape and size of different passages and chambers, which affected freedom of movement. The petrographic analyses have shown that almost the entire sample (forty-two out of forty-six specimens) is made of metamorphic rocks and, among these, mainly of rocks with an isotropic fabric belonging both to deep crust high-grade metamorphic units (metagabbro, metabasite, granulite), and to ophiolitic ones (glaucophanite); there are twentythree samples having such a feature.
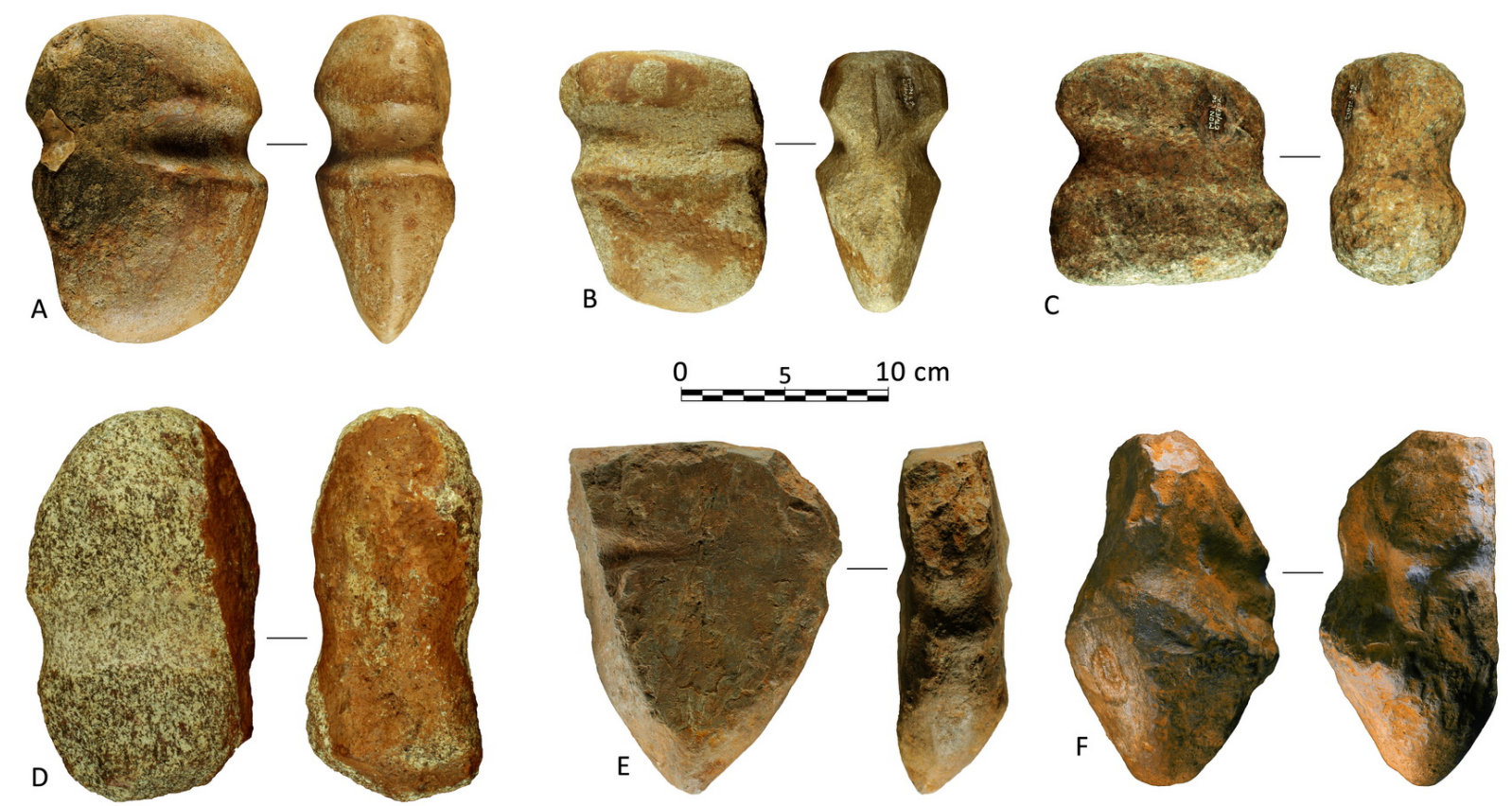

Figure 4. Grooved stone tools from the underground site of Grotta della Monaca (Sant'Agata di Esaro, Cosenza): A-B. hammer-axes, L1 / L7; C-D. hammers, L10 / L8; E-F. pickaxes, L222 / L34 (pictures by F. Larocca).

Among the other specimens, six of them have a cataclastic structure; in eight cases a preferred orientation structure (gneiss type) was observed; in seven cases a weakly schistose structure and in one case a markedly schistose structure (Acquafredda \& Piccarreta in press). Although low quality materials (such as schists, which show poor resistance to compression and tend to fracture according to the bedding planes) are also attested, all the more refined and elaborated instruments are made from raw materials with excellent mechanical properties. These raw materials occur along the banks of the Esaro River, a few kilometres south of the site, where it intercepts extensive outcrops of crystalline metamorphic rocks of the lower crust, but also ophiolitic formations. In this area the river carries a broad variety of rock types, which can be found in the form of more or less rounded pebbles of wide size variability. Such a selection suggests a good knowledge of the mechanical features of the different rock types by miners working in this area during prehistory.

\section{Results}

Our study confirms that grooved stone tools are exceptionally popular throughout the region. From north to south the whole of Calabria shows - through the museum's collections, the paleo-ethnological literature and the recent discoveries - a marked presence of this type of object, generally attributable to late prehistory (from the late Neolithic to the early age of metals). Their presence is even more surprising when compared with neighbouring regions where the tools are rare to non-existent. 
Table 3. ID and quantitative data of the twenty-two intact, or almost intact, grooved stone tools unearthed within Grotta della Monaca. Abbreviations: L - length (cm); Wd - width; MT - maximum thickness (cm); AWd average width (cm); AD - average depth (cm); Wt - weight (grams).

\begin{tabular}{|c|c|c|c|c|c|c|c|c|}
\hline \multirow[b]{2}{*}{ ID } & \multirow[b]{2}{*}{ Type } & \multirow[b]{2}{*}{$\mathbf{L}$} & \multirow[b]{2}{*}{$\mathbf{W}$} & \multirow[b]{2}{*}{ MT } & \multirow[b]{2}{*}{ Hafting Method } & \multicolumn{2}{|c|}{ Hafting Index Measures } & \multirow[b]{2}{*}{ Wt } \\
\hline & & & & & & AWd & AD & \\
\hline L1 & hammer-axe & 15.9 & 11.7 & 6.3 & groove & 3.3 & 0.8 & 1912 \\
\hline L3 & hammer & 10.8 & 8.3 & 3.8 & groove on 3 sides & 2.8 & 0.6 & 646 \\
\hline L5 & pickaxe & 15.9 & 10.7 & 9.3 & groove on 3 sides & 1.2 & 0.1 & 2252 \\
\hline L6 & hammer & 9.7 & 9.1 & 4.8 & groove & 2.0 & 0.3 & 677 \\
\hline L7 & hammer-axe & 12.7 & 9.0 & 6.2 & groove on 3 sides & 3.1 & 0.8 & 1043 \\
\hline L8 & hammer & 19.1 & 12.0 & 8.5 & groove & 3.8 & 0.5 & 3115 \\
\hline L10 & hammer & 11.3 & 11.7 & 6.3 & groove & 3.5 & 0.8 & 1749 \\
\hline L11 & hammer-axe & 12.1 & 8.8 & 3.8 & groove & 2.0 & 0.4 & 321 \\
\hline L13 & hammer & 10.8 & 9.5 & 4.8 & groove on 3 sides & 1.9 & 0.5 & 885 \\
\hline L14 & hammer & 13.0 & 11.0 & 5.3 & 2 notches & $\begin{array}{c}1^{\text {st }} \text { notch } \\
1.5 \\
2^{\text {nd }} \text { notch } \\
2.0\end{array}$ & $\begin{array}{c}1^{\text {st }} \text { notch } \\
0.5 \\
2^{\text {nd }} \text { notch } \\
0.5\end{array}$ & 1262 \\
\hline L18 & pickaxe & 13.7 & 9.3 & 9.3 & groove and 2 notches & $\begin{array}{c}\text { groove } \\
2.1 \\
1^{\text {st }} \text { notch } \\
1.6 \\
2^{\text {nd }} \text { notch } \\
1.5\end{array}$ & $\begin{array}{c}\text { groove } \\
0.7 \\
1^{\text {st }} \text { notch } \\
0.2 \\
2^{\text {nd }} \text { notch } \\
0.15\end{array}$ & 1788 \\
\hline L21 & hammer & 13.0 & 10.0 & 7.4 & groove and notch & $\begin{array}{c}\text { groove } \\
1.9 \\
\text { notch } \\
2.3\end{array}$ & $\begin{array}{c}\text { groove } \\
0.4 \\
\text { notch } \\
0.5\end{array}$ & 1460 \\
\hline L34 & pickaxe & 17.2 & 10.5 & 9.0 & 3 notches & $\begin{array}{c}1^{\text {st }} \text { notch } \\
2.3 \\
2^{\text {nd }} \text { notch } \\
1.5 \\
3^{\text {rd }} \text { notch } \\
2.7\end{array}$ & $\begin{array}{c}1^{\text {st }} \text { notch } \\
0.4 \\
2^{\text {nd }} \text { notch } \\
0.5 \\
3^{\text {rd }} \text { notch } \\
0.6\end{array}$ & 2010 \\
\hline L37 & hammer & 11.3 & 7.2 & 7.0 & groove on 2 sides & 2.2 & 0.1 & 1144 \\
\hline L38 & hammer & 12.3 & 10.3 & 8.0 & groove on 3 sides & 2.6 & 0.5 & 1647 \\
\hline L64 & hammer & 11.8 & 11.3 & 5.2 & groove & 2.5 & 0.7 & 1151 \\
\hline L215 & hammer-axe & 15.9 & 9.4 & 5.6 & groove & 3.9 & 0.7 & 1525 \\
\hline L217 & hammer & 9.7 & 8.7 & 6.1 & groove & 1.9 & 0.2 & 786 \\
\hline L219 & hammer & 8.5 & 7.2 & 6,5 & groove & 2.4 & 0.8 & 636 \\
\hline L220 & hammer & 12.9 & 10.8 & 5,6 & groove & 3.1 & 0.8 & 1070 \\
\hline L221 & hammer-axe & 9.5 & 7.9 & 4.2 & groove & 2.1 & 0.5 & 617 \\
\hline L222 & pickaxe & 17.1 & 13.1 & 5.3 & 3 notches & $\begin{array}{c}1^{\text {st }} \text { notch } \\
1.9 \\
2^{\text {nd }} \text { notch } \\
2.0 \\
3^{\text {rd }} \text { notch } \\
1.8\end{array}$ & $\begin{array}{c}1^{\text {st }} \text { notch } \\
0.3 \\
2^{\text {nd }} \text { notch } \\
0.3 \\
3^{\text {rd }} \text { notch } \\
0.4\end{array}$ & 2060 \\
\hline
\end{tabular}


The exceptional discoveries in the site of Grotta della Monaca, in the northern part of Calabria, offer an unexpected key to understand the main function of these tools.

At this site they are unequivocally linked to mining activities carried out for the procurement of precious subterranean minerals. Most of the instruments are scattered around underground areas where copper carbonates outcrop (malachite and azurite) and this may indicate their specific use for the exploitation of this resource, although we do not exclude a parallel use of the same tools for the acquisition of iron ore, especially hydroxides such as goethite, also very common in the cave (Figure 5 A-D).

We have to consider that the exploitation of these minerals is not related to metallurgical purposes. In fact, the amount of pure metal potentially obtainable from their fusion is minimal and uneconomic. More likely, they may have been used as pigments but other domestic uses cannot be excluded (e.g., raw hide processing, realization of adhesive substances, pharmacology).
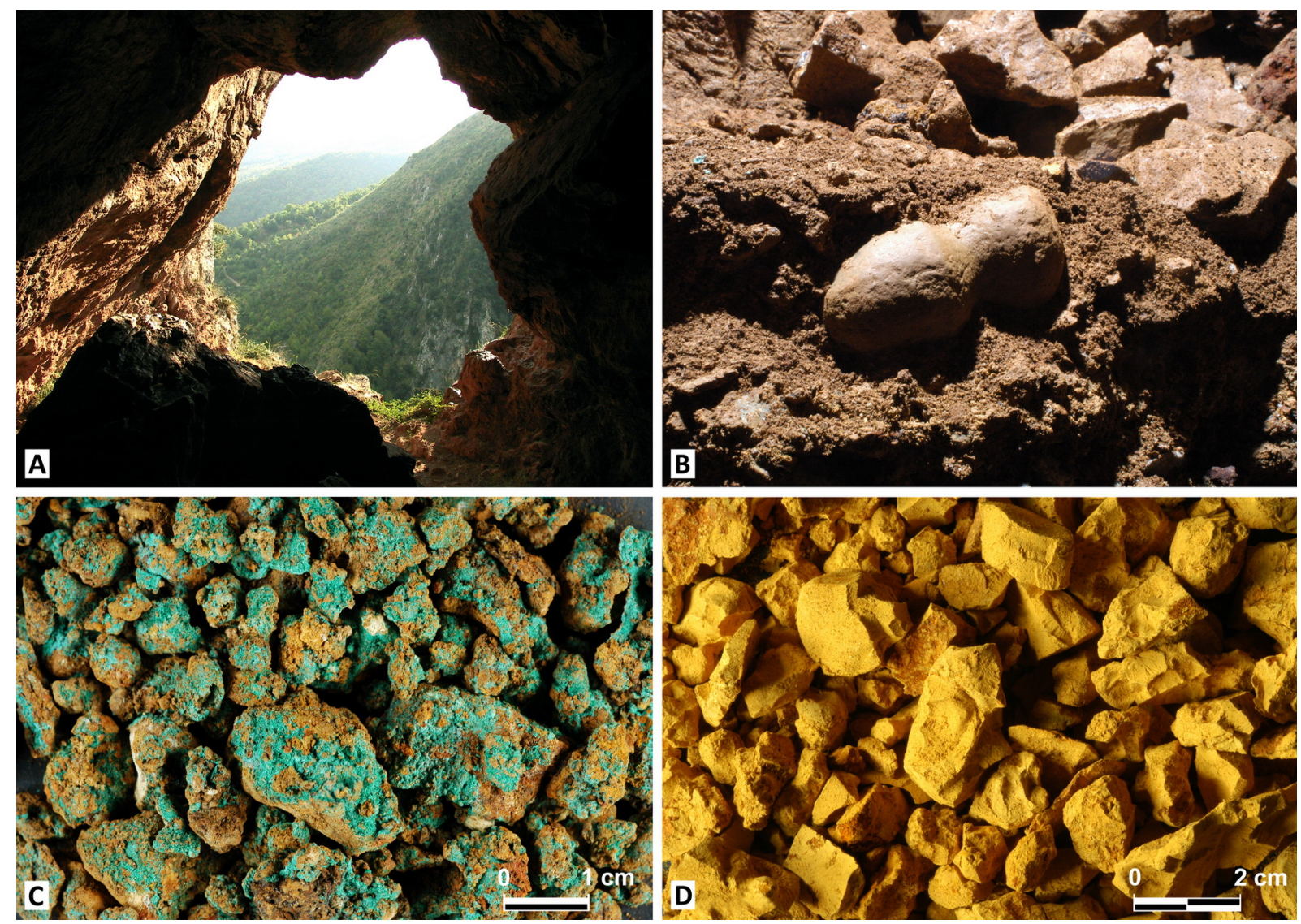

Figure 5. Grotta della Monaca (Sant'Agata di Esaro, Cosenza): A. entrance seen from the inside of the cavity; B. grooved hammer-axe half-buried in the sediment; C. lumps of malachite on fragments of limestone; D. crushed blocks of goethite (A: picture by D. Lorusso; B-D: pictures by F. Larocca).

The case of Grotta della Monaca, located in an area with a strong and well-documented mining history over the last thousand years, provides us with fresh insight in regards to the many finds of grooved tools within $10 \mathrm{~km}$ from this site. Especially, it has shown a correlation between confirmed presence of mineralization, mainly metallic ores, and the occurrence of this type of artefact. This happens, for example, in San Donato di Ninea and Acquaformosa, a few kilometres northeast from Grotta della Monaca, where there are reported deposits of gold, silver, iron, copper and cinnabar. In the countryside of these two locations, grooved hammer-axes have been frequently found, unfortunately not by archaeologists and scholars, who could have properly investigated the context, but by locals 
who collected these items just for their singular shape. Their later recollections concerning the find locations of these items are often vague. Similar patterns occur elsewhere, such as in Longobucco, in the northern foothills of the Sila. Silver-rich galena mines are known to date back to the $12^{\text {th }}$ century CE and once again in this territory grooved tools have been found, currently kept at the Museo Nazionale Preistorico Etnografico "Luigi Pigorini” in Rome.

The direct correlation between grooved tools and prehistoric mining activity is not always and unequivocally valid: indeed, these instruments can also be used for many other purposes and often they are defined as multi-purpose tools, adaptable to different uses. However, the overall picture leads us to the conclude that the overlap witnessed between the regions in which ore deposits are known and the distribution of pre-protohistoric grooved lithic tools, is not accidental. Additionally, apart from Grotta della Monaca, the absence so far of direct and clear evidence of prehistoric mining (mines, quarries, trenches, etc.), does not prove that it did not exist. This is even more likely in those areas that have been mined extensively in the last few centuries, with relatively recent extractions that, almost always, destroy traces of earlier extractions.

By comparing geo-mineralogical and historical mining activities and the geographical spread of grooved stone tools, and removing cases where the tools likely indicate different activities, three specific district of Calabria have been identified as areas likely to produce evidence of prehistoric mining in the future (Larocca \& Breglia 2012). We recognize, from north to south, a northwestern district, a district in the central-eastern part of the region, and finally, a southeastern district (Figure 6A). The first district is currently the most important one because of the proven presence of prehistoric mines (Grotta della Monaca and another minor site, Grotta del Tesauro, not far from the first cavity) (Larocca \& Breglia 2014). The other two districts - far larger than the previous - are those in which the presence of mines or prehistoric mining activities is highly likely, although so far their exact location is still unknown. In the latter two cases these minerals occur as very visible, surface outcrops, which may help to explain the concentration of grooved tools in these areas (Figure 6B).

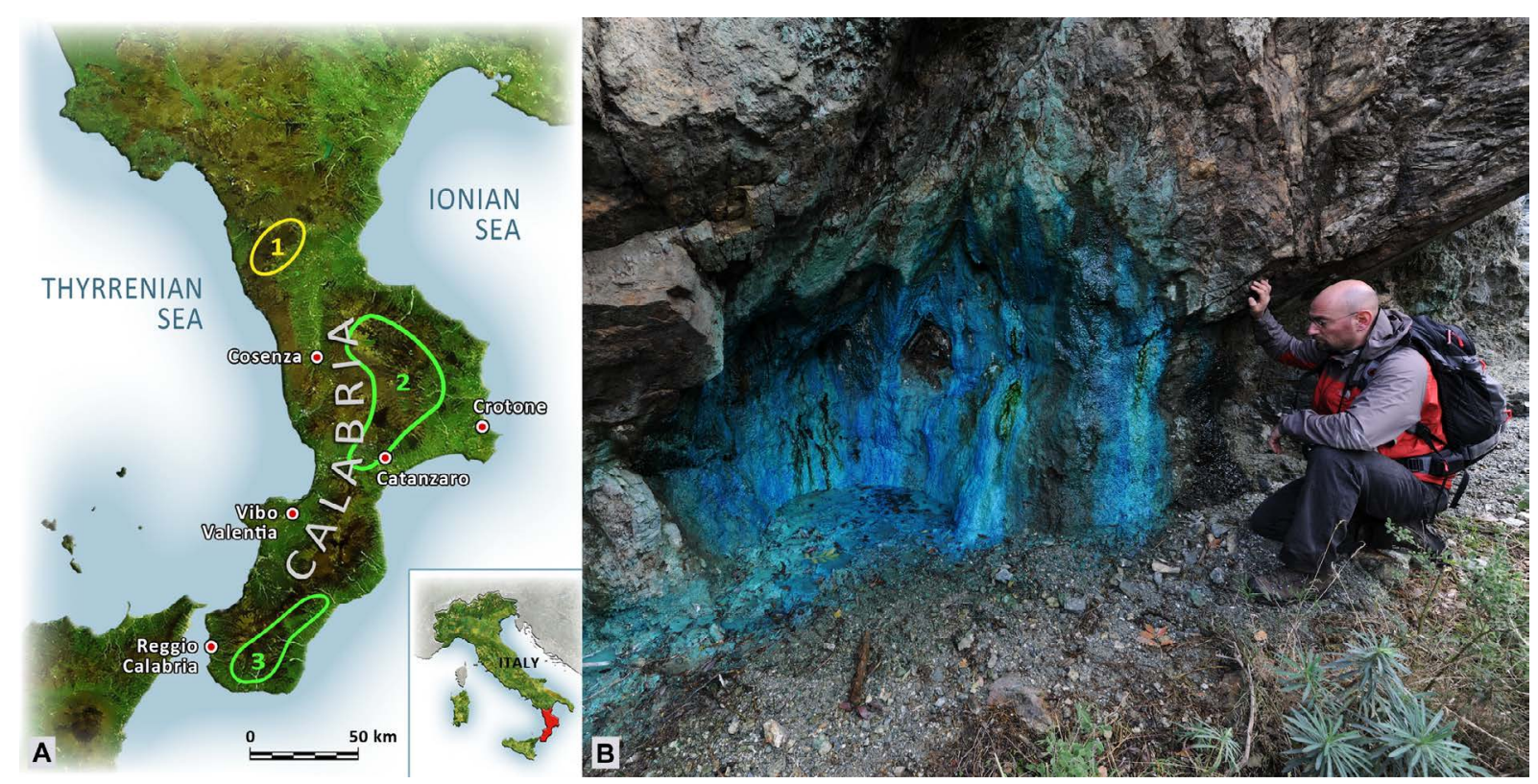

Figure 6. A. Map of Calabria with indication of the three prehistoric mining districts, one of which is certain (in yellow, 1) and two probable (in green, 2-3); B. Outcrops of copper ore in the third district, the south-eastern one (A. Design by F. Breglia; B. Photo by F. Larocca). 


\section{Conclusions}

The identification of ancient mining activities is almost always rather difficult due to several reasons: natural alteration of the original contexts, disturbance caused by human activities, impact of subsequent mining activities, etc. Nevertheless, available data on grooved stone tools found within areas where high concentrations of these objects have been found can be used to try to identify prehistoric mining structures or contexts. Grotta della Monaca provides interesting insight into the nature of prehistoric mining: karst caves located in areas rich in ores can be a particularly convenient gateway to easily accessed underground resources. Moreover karst cavities, especially when developing in carbonate rocks, are usually structurally more stable and durable than many artificial mines within other geological terrains, which are often prone to surface disintegration and collapse. Although the mining of natural caves represents an extraordinary and infrequent case, we propose that all natural caves with ore deposits be searched for these tools. This approach has been successfully applied in the case of Grotta del Tesauro, in the territory of Sant'Agata di Esaro (Cosenza): in this cave, rich in iron mineralization, the archaeological excavations led to the discovery of grooved tools associated with pottery from the early Copper Age (first half of the fourth millennium BCE). Although there is no evidence of prehistoric mining activities, the association of these types of tools with underground sites is significant.

It is important, therefore, to carry out targeted surveys in all areas where grooved tools are frequently displayed in museums and other collections. From this point of view, the most interesting case is currently represented by the territory of Roccaforte del Greco, in the extreme south of the region (district 3 of Figure 6:A). In this area, which completely lacks the karst phenomena typical of northern Calabria, several grooved tools were found. About ten kilometres west of Roccaforte del Greco, significant copper ore deposits are well-known, exploited until a few centuries ago (locality Trunca, town of Montebello Ionico). Based on our current state of knowledge, we do not know if we can correlate the abundance of grooved artefacts from Roccaforte del Greco with the ore deposits of Trunca, but their simultaneous presence is promising. We are at the early stages of an investigation that promises to be interesting and challenging: thorough investigation of the identified regional districts, through surveys and observations in the field, we will soon fully confirm or challenge our research hypotheses.

\section{References}

Acquafredda, P., \& Piccarreta, G., in press, I manufatti litici: aspetti petroarcheometrici. In: Grotta della Monaca. Studi e Ricerche I (Larocca F., Ed.), Centro Regionale di Speleologia "Enzo dei Medici”, Roseto Capo Spulico: p. 65-103 (in Italian) (“The lithic artefact: petro-archaeometric aspects”)

Amodio-Morelli, L., Bonardi, G., Colonna, V., Dietrich, D., Giunta, G., Ippolito, F., Liguori, V., Lorenzoni, S., Paglionico, A., Perrone, V., Piccarreta, G., Russo, M., Scandone, P., Zanettin-Lorenzoni, E., \& Zuppetta, A. 1976, L'Arco calabro-peloritano nell'orogene appeninico-maghrebide. Memorie della Società Geologica Italiana, 17: 1-60. (in Italian) ("The Calabria-Peloritani Arc in the Apenninic-Maghrebian orogen”)

Bonardi, G., De Vivo, B., Giunta, G., Lima, A., Perrone, V., \& Zuppetta, A. 1982, Mineralizzazioni dell'arco calabro-peloritano. Ipotesi genetiche e quadro evolutivo. Bollettino della Società Geologica Italiana, 101: 141-155. (in Italian) ("Mineralization of the Calabria-Peloritani Arc. Genetic hypotheses and evolutionary framework") 
Guarascio, M. 1982, Un contributo di dati e metodi della ricerca geomineraria in archeologia: il caso di Temesa. In: Temesa e il suo Territorio (Maddoli G., Ed.), Atti del Colloquio di Perugia e Trevi, 30-31 maggio 1981 Istituto per la Storia e l’Archeologia della Magna Grecia, Taranto: p. 125-142. (in Italian) ("A contribution of data and methods from geo-mineral research to archaeology: the case of Temesa”)

Larocca, F., (Ed.), 2005, La miniera pre-protostorica di Grotta della Monaca (Sant'Agata di Esaro - Cosenza). Centro Regionale di Speleologia “Enzo dei Medici”, Roseto Capo Spulico, 98 p. (in Italian) ("The pre-protohistoric mine of Grotta della Monaca (Sant’Agata di Esaro - Cosenza)”)

Larocca, F. 2010, Grotta della Monaca: A prehistoric copper and iron mine in the Calabria region (Italy). In: Mining in European History and its Impact on Environment and Human Societies. Proceedings for the $1^{\text {st }}$ Mining in European History - Conference of the SFB-HIMAT (Anreiter P., Goldenberg, G., Hanke, K., Krause, R., Leitner, W., Mathis, F., Nicolussi, K., Oeggl, K., Pernicka, E., Prast, M., Schibler, J., Schneider, I., Stadler, H., Stöllner, T., Tomedi, G., Tropper, P., Eds.), Forschungszentrum HiMAT, Innsbruck: p. 267-270.

Larocca, F., \& Breglia, F. 2014, L’alta valle dell’Esaro e le sue miniere preistoriche. Speleologia, 71: 30-36. (in Italian) (“The upper Esaro valley and its prehistoric mines”)

Larocca, F., \& Breglia, F., 2012, Grooved Stone Tools as Indicators of Ancient Mining Activities. Evidence from Calabria Region (Italy) (poster) presented at the $2^{\text {nd }}$ Mining in European History - Conference, The Impact of Historic and Prehistoric Mining Activities on the Environment and Societies in Europe, Innsbruck, 7-10 November 2012.

Lovisato, D. 1878a, Di alcune azze, scalpelli, martelli e ciottoli dell'epoca della pietra trovati nella Provincia di Catanzaro. Bollettino della Societa Adriatica di Scienze Naturali in Triste, 3: 475-505. (in Italian) (“About some axes, chisels, hammers and pebbles of the stone age found in the province of Catanzaro")

Lovisato, D. 1878b, Strumenti litici e brevi cenni geologici sulle province di Catanzaro e di Cosenza. Tip. Salviucci, Roma, 22 p. (in Italian) ("Stone tools and brief geological references about the provinces of Catanzaro and Cosenza")

Salerno, A., \& Pessina, A. 2004, Le asce in pietra levigata della Calabria nelle collezioni del Museo Pigorini. In: Preistoria e Protostoria della Calabria, Atti della XXXVII Riunione Scientifica dell'Istituto Italiano di Preistoria e Protostoria, Scalea, Papasidero, Praia a Mare, Tortora, 29 settembre-4 ottobre 2002, Vol. 2, Instituto Italiano di Preistoria e Protostoria, Firenze: p. 765-771. (in Italian) (“The polished stone axes from Calabria in the Pigorini Museum collections”)

Topa, D. 1927, Le Civiltà Primitive della Brettia. Paletnologia. Stabilimento Tipografico (Genovesi, A., \& Figli, Eds.), Palmi, facsimile reprint (ristampa anastatica) (1980), Barbaro Editore, Oppido Mamertina, 200 p. (in Italian) ("Primitive civilizations of Brettia. Palethnology”)

De Vivo, B., Closs, L.G., Lima, A., Marmolino, R., \& Perrone, V. 1984, Regional geochemical prospecting in Calabria, Southern Italy. Journal of Geochemical Exploration $\left(10^{\text {th }}\right.$ International Exploration Symposium - $3^{\text {rd }}$ Symposium on Methods of Geochemical Prospecting), 21(1-3): 291-310. doi:10.1016/0375-6742(84)90055-4 